\title{
The Construction of Racial and Social Difference through Securitizing Mobility. Viapolitics and the Disputing of Citizenship of Roma
}

\author{
Huub van Baar
}

\section{Abstract}

This chapter uses the case study of the European Roma to demonstrate the importance of mobile governmentalities in regulating mobility and citizenship. These are political technologies in which mobility itself is turned into a strategy to govern mobility, particularly through keeping people on the move. Whereas most studies about mobility and migration focus on the governing of mobilities and on interrelated biopolitical mechanisms, I extend these investigations to mobile governmentalities, which include what I call governance and securitization through 'nomadization', as well as through what William Walters calls 'viapolitics'. The latter is a form of governance that considers vehicles, routes and journeys as mobile sites of power and contestation in their own right. Through an examination of a historical case study about Dutch Roma, I show that not only camps and halting sites, but also vehicles and mobility itself are to be understood as technologies of governing minorities such as Roma along racial and security lines, thereby turning them into irregular citizens.

\section{Introduction: Analyzing Mobilities of Roma beyond the State of the Art}

In this chapter, I focus on the production of social and mostly racial difference through the securitization of mobility, primarily in the field of citizenship and regarding what, following pioneering research in citizenship studies (cf. Nyers 2019), I call citizenship irregularization. Here, I understand the verb 'irregularize' and the noun 'irregularization' as terms that are related to what is often understood as a relatively undisputed 'status' of being 'irregular' - such as in the qualification of being an 'irregular migrant'. To avoid considering this status in a reified way and to underscore that regular and irregular statuses are based on processes of differentiation, I speak of processes of citizenship irregularization. The central case study in which I will explore the articulation of these mechanisms of irregularization is that of the position of Sinti and Roma - and particularly the caravan dwellers among them - in $20^{\text {th }}$ century Dutch 
history. Conceptually my inquiry is based on a relatively new framework of political scientific analysis, which William Walters (2015a, 2015b) has recently introduced under the term "viapolitics". I will explain its meaning further below and first give a rough overview of the current state of the art in the literature on the mobility of Roma.

\section{State of the Art: 'Camps' as political technologies of 'protected' sedentarization}

In scholarship on the situation of Roma minorities, much attention has been paid to the history of their mobilities and to the ways in which these have been governed throughout the ages, by themselves but mostly by others, including various kinds of authorities, ranging from Churches, tax collectors, towns, guilds and nobilities to the police and a huge variety of other governmental officials at various institutional levels, including, more recently, supranational and intergovernmental ones. In this historiographical tradition, and in the West European context in particular, much attention has been dedicated to the ambiguous role that camps and encampments have played in the perception of their mobilities and, thus, in practices of (outside) identification and, to a lesser extent, processes of identity formation and the articulation of minority agency. In these historiographies, the analysis of the societal and cultural manifestation and representation of camps varies substantially. This analysis ranges from camps with wagons (romanticized or not), separated or segregated neighborhoods and concentration camps to urban and rural contained or semicontained spaces such as ghettoes, slums, shantytowns, refugee camps, (un-)organized halting sites and (un-)authorized camps for Roma, Gypsies or Travellers.

Various studies that analyze the relations between authorities and Roma, Gypsies and Travellers emphasize the ambiguous role that 'Gypsy camps' have played in these relationships. Following Michel Foucault's understanding of technologies of government, ${ }^{1}$ Giovanni Picker, Margaret

1 Foucault discussed the relevance of political technologies in several of his works, most notably in Discipline and Punish (1975/1995) and in his work on governmentality and counter-conduct (2007). Elsewhere (van Baar 2011a), I have extensively discussed how we could analyze the situation and history of Roma in Europe from the perspective of governmentality and, more specifically, from the angle of triple intersections of rationalities, technologies and strategies of government and how these have historically been mobilized to problematize Roma and their living conditions. 
Greenfields and David Smith have suggested that "the 'Gypsy camp' can heuristically be viewed as a spatio-racial political technology, namely as a largely supported and self-legitimizing policy device which sanctions the perfect juxtaposition of a racially connoted marginalized population with a secluded urban location, eventually crystallizing racist perceptions and public attitudes towards RGT [Roma, Gypsies and Travellers] onto the urban space and landscape" (Picker et al. 2015, p. 742; cf. Picker 2017, pp. 101-103). As the authors emphasize, particularly since the 1960 s the 'Gypsy camp' as a spatio-racial political technology — a technology that they trace back to colonial means of governing 'unruly' populations-has begun to function as a tool to combine governmental ambitions to 'sedentarize' 'nomadic' groups with cultural policies dedicated to the 'protection' of 'their way of life', thus, their tradition of 'nomadism': 2

"The drive to sedentarize nomadic populations in isolated places stemmed from the governmental presumption, emergent across Europe during the 1960s, that itinerants needed a place to stop in order to become incrementally integrated into mainstream society without totally losing their 'way of life'." (Picker et al. 2015, p. 742)

And indeed, after the Second World War strategies of governing that combined sedentarization with forms of minority 'protection' were articulated in several, mostly West European countries. The United Kingdom and Italy are good examples, and also in post-war France and the Netherlands similar governmental attempts to deal with 'unruly' populations with a Roma background were introduced.

In addition, what happened at various national levels was leading the Council of Europe to articulate these attempts at the European level, now with a clearer but not necessarily less ambiguous dimension of minority recognition through safeguarding their protection. For instance, from the late 1960s onwards, the Council adopted several resolutions and recommendations dealing with the situation of people who, depending on the period and the discursive framing that then dominated, were referred to as 'Gypsies and other travellers' (1969), 'Nomads' (1975-87), 'populations of nomadic origin' (1981-84), 'Gypsies' (1983-95), 'Gypsies and Travellers' (1987), 'Gypsies (Roma and Sinti)' (1995), 'Roma/Gypsies' (1995-2000) or

2 I put the terms 'sedentarize', 'protection', 'their way of life' and 'nomadism' in inverted commas because, as I show throughout this paper, these terms have become very delicate, politicized terms in the history of the governing of Roma, Gypsies and Travellers. 
'Roma' (since 1995). A 1975 resolution explains that, "the expression 'nomads' means persons who for historical reasons are accustomed to following an itinerant way of life, as well as persons of nomadic origin who experience difficulties in integrating into society for sociological, economic or similar reasons" (Council of Europe 1975 in Danbakli 2001, p. 125, emphasis added). Both highlighted expressions - 'for historical reasons' and 'persons of nomadic origin' - are remarkable for the way in which they project the reasons for following an 'itinerant way of life' onto the past and, thus, for how the alleged 'nomadism' of this minority is considered as a declining tradition or as one in jeopardy. In the former case, it is suggested that this lifestyle is a kind of remnant of the past that is still continued as an everyday practice of living, while, in the latter expression, it is insinuated that these persons are not 'nomadic' but only of 'nomadic origin'.

This framing is in line with the ways in which the Council of Europe's policies of the late 1960s and the 1970s problematize the situation of 'Nomads' or 'Gypsies': they do so from the perspective of the need for their social and cultural protection while, at the same time, it is suggested that their identity is threatened because of 'industrial and urban development', 'the extension of town and country planning' and 'discrimination on the part of the settled population' (ibid., emphasis added). In a classic manifestation of the differentiating binary of modern versus traditional societies characteristic of many modernization theories, it is stated that "the Gypsy population in Europe is severely affected by the rapid changes in modern society, which are depriving Gypsies and other travellers of many opportunities to carry on with their traditional trades and professions" (Council of Europe 1969 in Danbakli 2001, p. 144, emphasis added). Thus, the process of modernization itself is interpreted as endangering 'traditional' societies, trades, professions and 'lifestyles', such as those of 'Gypsies and other travellers'.

Both in various, mainly West European governmental approaches to Roma, Gypsies and Travellers and in the policy documents and practices of the Council of Europe, the calls for the 'protection' or even 'recognition' of these minorities' cultures and 'lifestyles' coincided with the observation that these lifestyles were at risk of vanishing due to the rise of 'modern' industrial societies and phenomena such as urban and rural planning and development. In this context, Picker, Greenfields and Smith accurately remark:

"By the mid-20th century, the 'problem' resulted from the declining position of Gypsies and other itinerants in relation to majority society as demand for their labor and tolerance of their 'difference' declined. 
Policy responses seeking to enforce sedentarization through making a nomadic life increasingly untenable represented one element of an assimilationist strategy targeted at 'outsiders' and 'deviants' which had developed throughout the 19th and 20th centuries." (Picker et al. 2015 , p. 745 , emphasis added)

No matter the accuracy of this observation, the mere focus on the assimilationist strategy and the underlying dynamics of 'sedentarization' through simultaneously questioning and protecting 'a nomadic lifestyle' does not help to get a good sense of the full scope and complexity of the governmental rationalities, technologies and strategies involved in how the lives and practices of Roma, Gypsies and Travellers have been politicized and depoliticized in post-war Europe - certainly not when we analyze them longitudinally and in the context of what has happened more recently in European history, since the emergence of what I have called 'the Europeanization of Roma representation' (van Baar 2011a). Nor does the mere focus on the 'Gypsy camp' as a spatio-racial political technology help us to understand the variety of governmentalities and counter-governmentalities involved in the racialized regulation of their lives, practices and 'difference'.

\section{Two Critical Interventions Beyond the State of the Art: Nomadization and Viapolitics}

For these reasons, I will make two closely related critical interventions in the current state of the art and both are directly related to political technologies of security and their impact on producing racial and social difference. My first intervention is one beyond the focus on sedentarization towards what I have called 'nomadization' (van Baar 2011b, 2015), while my second is one beyond the exclusive focus on biopolitics towards viapolitics. I have made the first of these interventions elsewhere (van Baar 2021), but will briefly outline it here since it is closely related to the second intervention, which I will motivate in this chapter.

Picker, Greenfields and Smith state that, in post-war (Western) Europe, the 'Gypsy camp' was a policy response to the dilemma: "how to protect an alleged nomadic lifestyle, while encouraging sedentarization" (Picker et al. 2015 , p. 747 , emphasis added). ${ }^{3}$ Alternatively, I want to suggest that

3 Though, in their paper, they reserve this specific description for the way in which Italian authorities dealt with Roma in Italy, the more general argument of the 
one of the leading parallel governmental strategies has tried to answer to the dilemma of how 'settlement' could be prevented through encouraging nomadization. 'Nomadization' (van Baar 2011b, 2015) is a strategy of governance that enforces mobility through the active irregularization of the involved individual's or collective's mobility. Irregularization (Nyers 2019, pp. 2233 , cf. van Baar 2015) refers to the more general processes and mechanisms through which a status, practice or act of citizenship is made 'irregular'. As I have indicated above, the concept acknowledges that notions such as 'irregular migrants' or 'regular citizens' do not refer to static states of affairs but to reified, temporary and contestable outcomes of political processes that 'regularize' and 'irregularize' people. There are various strategies that contribute to the production of irregular citizenship and 'nomadization' is one of them and often articulated in combination with overlapping strategies of, for instance, stigmatization, orientalization, criminalization, racialization and securitization.

Following this intervention, I have argued that not only assimilation through 'sedentarization', but also expulsion through 'nomadization' has been among the key strategies of governing that have dramatically affected the situation of Roma, Gypsies and Travellers in Europe, as well as the maintenance and reproduction of their ostensible ethnic-racial 'difference', throughout the twentieth century and up till now (van Baar 2021). Nomadization is a mechanism that overlaps with, but also differs from (spatial) displacement through expulsion; it refers to a mechanism that tries to keep people on the move or to maintain or produce the conditions that contribute to what I have called the 'perpetual mobile machine of forced mobility' and the interrelated 'institutionalization of rootlessness' (van Baar 2015). Among these conditions are those of 'evictability' (van Baar 2017), that is the possibility of being removed from a sheltering place; conditions that have significantly contributed to a situation of highly contained mobility (van Baar 2018, 2019) regarding Europe's Roma.

To grasp the full scope of the diversity of Roma-related governmentalities and counter-governmentalities, in this chapter I will make a second intervention and argue that we should also look beyond the trope and technology of the 'Gypsy camp', as well as beyond the interrelated biopolitical strategies and technologies of government. We should consider the role of what Walters calls viapolitics. Analyses of mobilities in migration studies, Walters (2015b, p. 98) accurately observes, often "tend to see the

paper clarifies that they consider this qualification relevant in a more general sense of what happened in post-war Western Europe. 
movement of people and things in terms of how movement is produced, regulated, surveilled and contested." Undoubtedly, the 'mobilities turn' in the humanities and the social and political sciences has contributed to the contestation of sedentarist assumptions and methodologies in social and political thought. Nevertheless, the role and meaning of vehicles, roads, routes, journeys and vessels in how they channel and challenge the movements of people and things have so far been largely undertheorized. ${ }^{4}$ This observation has led Walters $(2015 \mathrm{a}, 2015 \mathrm{~b})$ to introduce the notion of 'viapolitics'. In a somewhat similar way in which Foucault's concept of biopolitics involves the dimension of 'bios' (health, hygiene, productivity, subsistence, preservation of life) in how politics operates, viapolitics is concerned with the dimension of 'via' in how politics functions, emerges and redirects. Here, 'via' refers to "the in between, the en route, the places on the way", "the specific means of transportation and communication", as well as to the ways in which the vehicular, roads, routes and journeys can provide "a locus for problematizations of the human and for the possibility of politics" (Walters 2015a, pp. 471f., emphasis original).

In this chapter, I will show the relevance of viapolitics at its intersection with biopolitics. I limit my analysis of viapolitics to the role that the caravan or 'living wagon' (woonwagen in Dutch) has played in the twentieth-century history of Dutch policies towards caravan dwellers - who are called woonwagenbewoners in Dutch policy discourses -, a group that includes people with and without a Roma or Sinti background and that, following the post-1989 trend to Europeanize Roma representations (van Baar 2011a), can be considered as belonging to the umbrella term 'Roma'. Viapolitics involves more than just vehicles, but the case of the living wagon is exemplary for how the via-political dimension of Roma-related governmentalities has contributed to a substantial irregularization and racialization of their citizenship over the last century. While my Dutch case study is by no means isolated, more research into the transnational dimensions of viapolitics is to be welcomed to understand regional parallels and differences within and beyond Europe.

\section{Governing Roma Mobility and their 'Living Wagons' through Viapolitics}

Before the town, there was the road to the town and "there are towns because there is police," as Foucault (2007, p. 337) summarized one of the

4 Walters (2015a, 2015b) discusses various notable exceptions. 
key ideas of some $17^{\text {th }}$ and $18^{\text {th }}$-century police scientists. In his discussion of the emergence of police as a practice of governmentality, as Walters (2015b) notices, Foucault pays quite a lot, though no systematic attention to institutions prior to police, such as the mounted constabulary which, in Early Modern Europe, was responsible for controlling "people on the road" (Foucault 2007, p. 336). In this context, Foucault suggests, the road network feeding the market had to be governed and, therefore, in the seventeenth and eighteenth century "police was thought essentially in terms of what could be called the urbanization of the territory [that is] ... arranging things so that the territory is organized like a town, on the model of a town, and as perfectly as a town" (ibid., emphasis added).

I begin this section with this observation because, in the historicization of the governing of and through mobility, these via-political dimensions of technologies and strategies of governing have often been overlooked, not only regarding how they were articulated in the past, but also how they continue to play a vital role in contemporary contexts. Here, I discuss the history of governing vehicles in the Dutch policies regarding woonwagenbewoners over the last century. I focus on a few moments that are key to understand adequately their contemporary history. These cover the introduction of the laws of 1918 and 1968 - so-called 'caravan acts' or woonwagenwetten - and the later changes to these laws until the abolition of the 1968 Act in 1999.

In the late $19^{\text {th }}$ and early $20^{\text {th }}$ century, the arrival of the 'living wagon' in the Dutch landscape was increasingly problematized in terms of nuisance or a threat to public order and health. The living wagons, which were for the first time mentioned in Dutch censuses of 1879, were usually very basic and not equipped with places to sleep, even though wagons that offered sleeping places were gradually developed in the decades to come, also because a shortage of housing became increasingly urgent.

In 1911, this problematization of living wagons in terms of (in-)security led to the first national counting of wagons and their inhabitants: the authorities counted 2,800 inhabitants in 584 wagons, 402 of which with one room only (van Ooijen 1993, p. 71, pp. 83-87). The research carried out for this census also revealed that the vast majority of the inhabitants had never been accused of any penal act and that they were generally no 'aliens'; they usually had Dutch citizenship. The census also focused on whether the families living in the wagons had sufficient 'means of subsistence'. Furthermore, the census categorized the households on the basis of the number of adults and children, the number of rooms and the specific usage of the wagons (for work, permanent or non-permanent living, travelling, and/or transport or storage of goods). This census would 
become an important biopolitical tool in the development towards the official national policy that emerged after the end of the First World War.

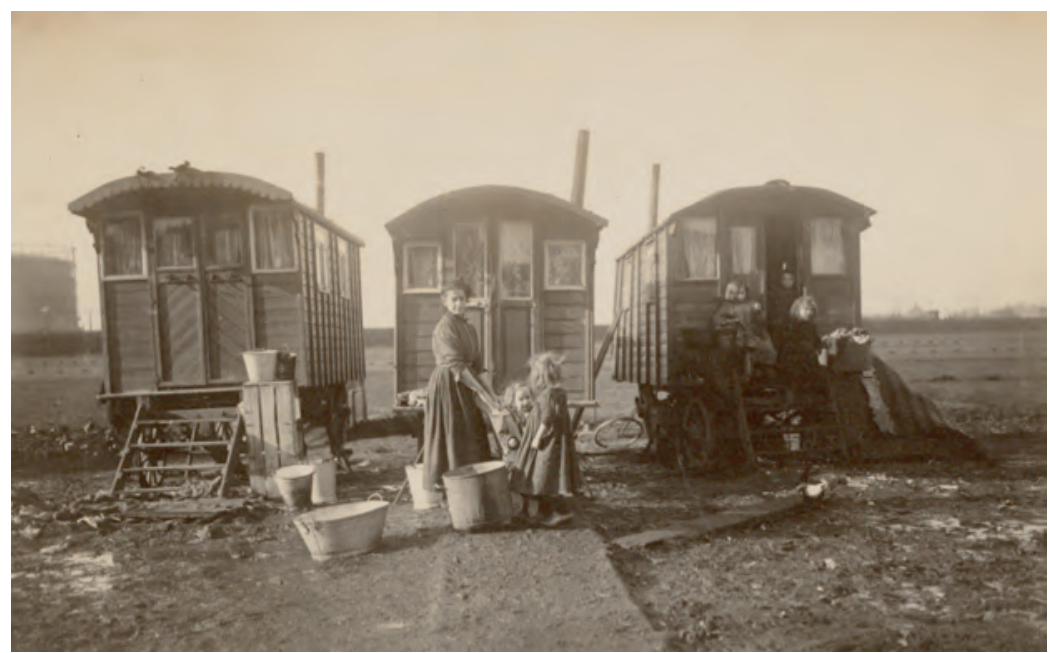

Fig. 1: Living wagons at the Notweg, Amsterdam, February 1910 (Stadsarchief Amsterdam / Photo Archive of the Police of Amsterdam)

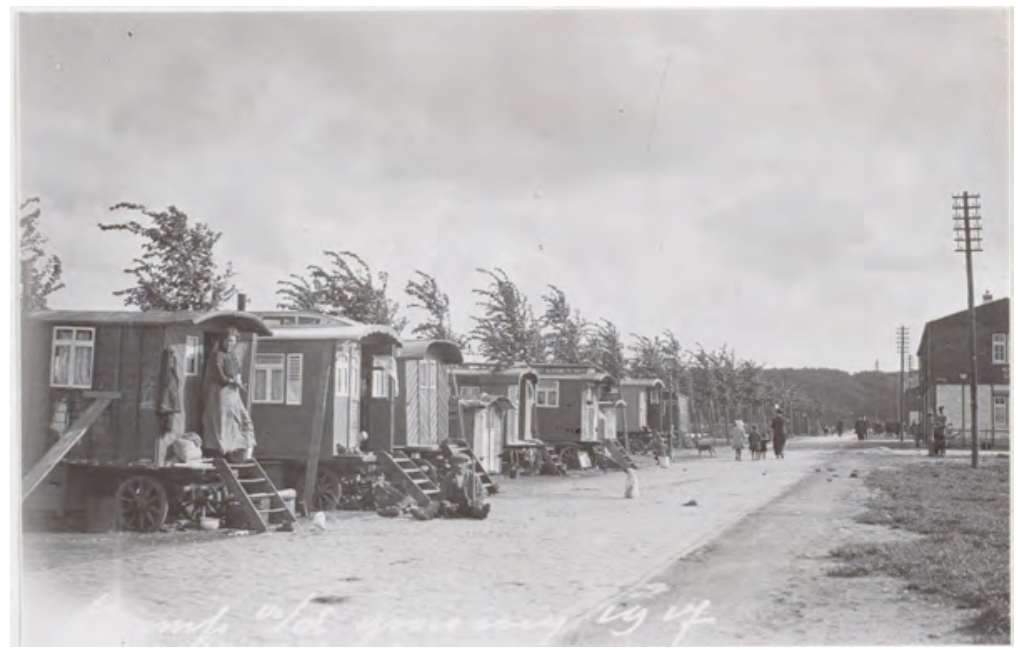

Fig. 2: Living wagons at the Grasweg, Amsterdam, 1917 (Stadsarchief Amsterdam; Photo: Jacobus van Eck) 
In the two decades preceding 1918, Dutch municipalities dealt mostly haphazardly with the living wagons and their inhabitants. In most cases, local governments tried to forbid the wagons or evicted them; practices that led to keeping their inhabitants constantly on the move and to shifting the responsibility to deal with them to ever-new municipalities. These practices led to calls for a national approach (van Ooijen 1993, pp. 71-116). Attempts of many MPs to forbid all living wagons turned out to be unrealistic when the war began and the financial means to build new houses lacked. Finally, the 1918 Act obliged all municipalities to offer sites on which woonwagenbewoners could live. The law included many regulations; here, I focus on those concerning the living wagon, because the impact of their management has been largely if not entirely neglected in the literature.

Article 1.1 of the Act prescribes that "the living wagon must rest on at least two axles and four wheels; the top of its floor may not be higher than 1 meter above the ground" (quoted in van Ooijen 1993, p. 104, emphasis added). ${ }^{5}$ Article 1.4 continues requiring that "the length, width and height of the living space must be at least 4.5, 2.1 and 2.1 meter (internal dimensions)," while article 1.5 states "that the living space must be divided into at least one day and one night space; day and night spaces must be separated from each other by a partition, in which a folding or sliding door [is available] ..." (ibid., p. 105). Among the most remarkable articles of the Act is the following:

"The number of persons who may maximally live in the wagon ... or have a night stay there may not, as a rule, be greater than the total volume of the rooms equipped for habitation in cubic meters, divided by 4 , whereas, at the outcome of this division, fractional parts have to be rounded up." (ibid.)

David van Ooijen (1993) has convincingly argued that the main aim of the law was to discourage people to live or continue living in a wagon and, by so doing, reducing the number of living wagons in the country. In a commentary on the Act's introduction, the then Minister of Justice stated that one of the aims of the government was "to treat all living wagons ... no longer on equal footing." He continued that "those who inhabit a suitably equipped vehicle ... and themselves obtain sufficient means of subsistence by lawful means must not be made difficult in their business. However, strong

5 All English quotations of van Ooijen are my translations. 
action must be taken against the others" (quoted in van Ooijen 1993, p. 89, emphasis added).

We can observe an important discrepancy between the way in which the aim of the law is stated here - primarily in terms of a distinction between the 'bad', 'criminal' woonwagenbewoners and the 'good', 'law-abiding' and 'self-sustainable' ones - and how this aim was translated into the text of the law. In the 1918 Act, the biopolitical knowledge of the 1911 census which clarified that the majority of wagons had only one room and were poorly equipped - was meticulously combined with the via-political tool to put the living wagon to a severe, if not totally unrealistic test. Officials involved in the law's composition could know that the requirements the law prescribed meant that the majority of living wagons would not come through the test and, thus, that this law would actively contribute to the illegalization of the woonwagenbewoners through targeting their wagons via-politically.

Yet, like most of the time, laws and policies work out differently in practice, even though it is particularly these unexpected outcomes that often offer important insights. There emerged a huge variety of municipal practices towards 'their' woonwagenbewoners. Many municipalities that took the law seriously created sites for them, but often deliberately on the margins of municipal territory and next to trash dumps or otherwise unattractive locations, reason why many caravan dwellers continued to move on from one municipality to the other, looking for better conditions. On the other hand, many municipalities that had already introduced their own regulations regarding woonwagenbewoners continued to rely on them and neglected the 1918 Act.

Importantly, already in 1918, the government created a so-called 'transitional provision' to take into account the fact that most wagons would not meet the introduced requirements. The government realized that strict law enforcement would cause massive homelessness and unemployment among woonwagenbewoners, an undesirable outcome that would cause other problems. Particularly when taking into consideration later developments, the following remark of the government regarding the Act's enforcement is striking:

"A slow extinction (langzame uitsterving) seems better so that the bad living wagons ... may still be inhabited during the life of the present main occupant or his wife ... If the ... transitional provision is broader in so far, on the other hand, it is now prohibited that permits will be granted to persons who have insufficient means of support. Bad living 
wagons will be tolerated for a while, not bad residents." (quoted in van Ooijen 1993, p. 111, emphasis added)

Thus, the law actively illegalized the wagons' inhabitants, but tolerated those with sufficient means of subsistence, mostly through tolerating the 'bad' conditions of many of their wagons, including the missing separation between living and sleeping parts. Consequently, the law produced both the conditions of evictability (van Baar 2017) and the irregularization of their citizenship that would be maintained throughout the twentieth century and into the third millennium. A new episode in the via-political bordering of woonwagenbewoners would only emerge in the 1960s. However, what happened during and immediately after the Second World War is crucial to understand its emergence.

The Un/Intended Consequences of Persecution Policies During the Second World War

The 1918 Act had missed its unofficial aim: Instead of reducing the number of woonwagenbewoners, the official institutionalization of living in a wagon had increased it, as well as the number of wagons - not the least because the general housing shortage had not diminished but only persisted; one of the reasons why also other citizens than the 'original' woonwagenbewoners were now living in wagons. In 1938, the then Dutch Minister of the Interior sent a letter to his colleague of Justice in which he urgently asked attention for a new phenomenon: increasingly more citizens, who could not pay the rent of reasonable housing, began living in differently constructed 'wagons'. He explained:

"Here, it does not concern a roaming population, but residents of the municipality who move into a woonwagen ... often on private terrain. Such wagons ... are generally not suitable for being moved ... The wagons are driven to a private site, where they are expanded and reinforced by all kinds of structures. The wheels are often left intact to demonstrate that it is for a stay to which the Housing Law ... does not apply ... [while the woonwagenwet does, $\mathrm{HvB}$ ] ... [The] wagons cannot drive and the wheels have only served to bring the constructed vehicle to the destination, after which they are sometimes removed to be used again for the next case ... In accordance with the provisions of Art. 31 of the [1918] Act, many municipalities have not designated a place where woonwagens ... must be located when staying within the municipality. Such a mandatory location fits the character of the nomadic population, for 
which the law is intended." (quoted in van Ooijen 1993, p. 155, 156, emphasis added)

The new practice that that minister described could be interpreted in different ways. For those who faced housing problems, this practice represented an inventive way to use the Caravan Act without belonging to the 'original' target group. For their large 'mobile homes' (stacaravans) they used removable wheels, so that nothing hindered these vehicles to be considered as 'living wagons' according to the 1918 Act. In this way, these new 'caravan dwellers' circumvented the regulations of the Housing Law and, instead, relied on the 1918 Act to turn their improvised living places into more or less permanent housing.

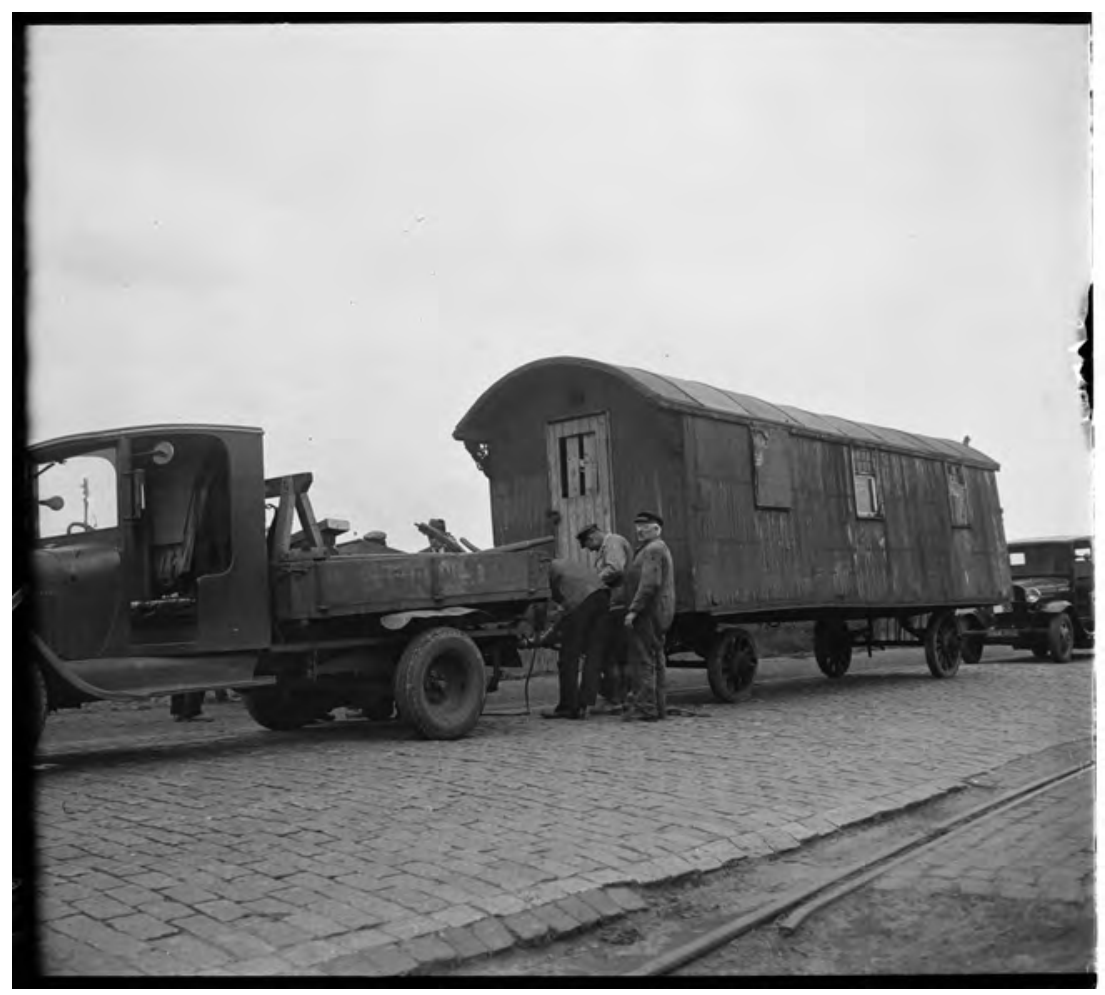

Fig. 3: Eviction of a living wagon from the camp at the Hemweg, Amsterdam, 17 May 1933 (Stadsarchief Amsterdam; Photo: Nico Swaager) 


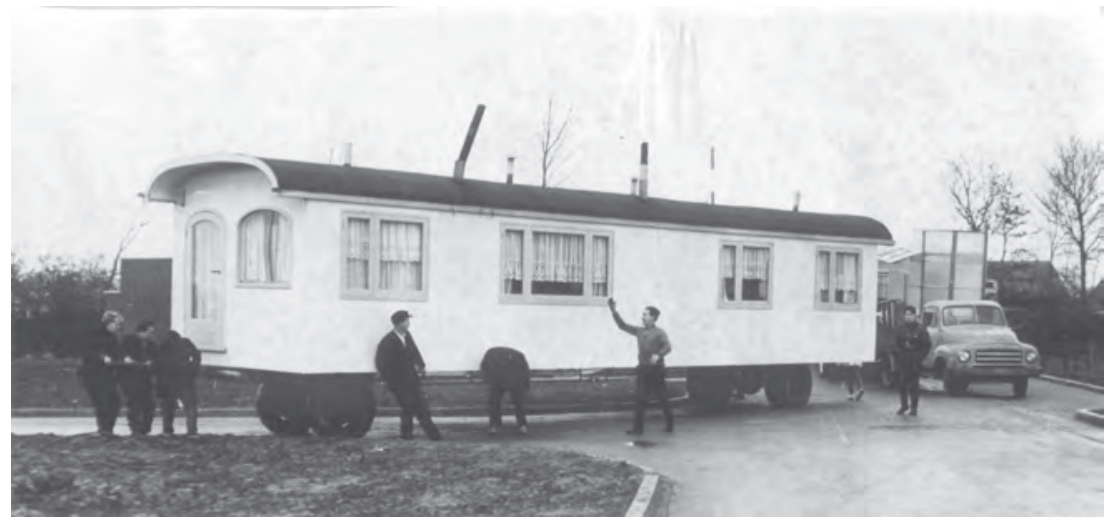

Fig. 4: Transportation of a living wagon to the center for living wagons (woonwagencentrum) at the Teersdijk in Nijmegen, 20 February 1967 (Regionaal Archief Nijmegen; Photo: J.F.M. Trum, CC-BY-SA F20914)

In reply to this practice, in July 1941 and more than a year into the Second World War, the Ministry of Justice prepared a draft policy according to which the 1918 Act would be exclusively applied to people with ambulant professions. Those who belonged to what was called the 'sedentary population' could not apply for a permit for a wagon and, accordingly, the law would now be explicitly limited to "the roaming population (zwervende bevolking) for whom the law was also originally meant" (quoted in van Ooijen 1993, p. 157). Thus, more than 20 years after the Act's introduction, which was primarily formulated along the via-political lines of what defined a 'living wagon', the government proposed redefining the law through creating a strict binary between 'roaming' and 'sedentary' populations. This shift away from a clearly via-political technology of managing populations was motivated by the fear that other people than the 'original' woonwagenbewoners would begin creating alternative housing outside the framework of the Housing Law and its requirements regarding what counted as 'housing'.

This development towards plans for redefining the 1918 Act coincided with another initiative that aimed at reducing the number of wagons by yet other means. On 24 July 1940, shortly after the German invasion in the Netherlands and about a month after the Dutch capitulation following the devastating Nazi bombardment of Rotterdam, L.A. van Doorn, the director of a municipal employment center in Utrecht, published the first of a series of four articles on the situation of woonwagenbewoners in a Dutch journal. Van Doorn claimed that "the current conditions" in the 
country were "perfectly appropriate" for the propagation of his policy plans for woonwagenbewoners. "Several obstacles, which would perhaps have been raised under different circumstances," he continued, "do not cause any difficulties now. We can act quickly, vigorously and effectively" (van Doorn 1940, quoted in van Ooijen 1993, p. 158). His plans included, among other measures, the establishment of a government "unity for the societal edification [maatschappelijke verheffing] of the population of woonwagenbewoners" with the aim to make them "slowly but surely fit for normal life and for the, for them, suitable jobs", a policy that should ultimately lead to the "disappear[ance] of the living wagons" (ibid., emphasis added).

Van Doorn's unorthodox plans did not manage to come through but, from early 1941 onwards, the Dutch police did begin to register extensively Dutch woonwagenbewoners, as well as monthly changes to their sites of residence; registers that were later used to carry out the Nazi orders to deport all so-called zigeuners (Gypsies) and zigeunerachtigen (Gypsy-like people) to the Nazi concentration camp in Westerbork. During the Nazi occupation of the Netherlands and in order to control the woonwagenbewoners, the Nazis forbade any movement of their wagons and first began to concentrate them in a few so-called 'collection camps' (verzamelkampen), thereby actively promoting the closure of many municipal halting sites and limiting their number to a few where all the woonwagenbewoners should be concentrated. Here, I will not focus on the human tragedies and the direct effects of what happened afterwards, including the severe persecution of woonwagenbewoners by both the Nazis and the Dutch police, attempts of many to go into hiding, and the horrific deportation of the Sinti and Roma among the woonwagenbewoners via Westerbork to Auschwitz-Birkenau. I rather concentrate on what could be considered as the unintended consequences of governmental plans and measures in the longer run, and on how these were partially caused by what happened during the war.

One of these 'unintended' outcomes is that what had been put under taboo in the Dutch policies regarding woonwagenbewoners before the Second World War, became the dominant way of governing their mobility in the first post-war decades. Soon after the war, large 'regional camps' were established or better, re-established, in larger regional municipalities, while the sites for wagons in smaller municipalities were to disappear (actually, to reappear again a few decades later, when it was acknowledged that this policy had 'failed').

Directly after the war, van Doorn saw the chance to reinvigorate his plans. He was among the policymakers who devised the new Dutch policy regarding woonwagenbewoners. In 1947, he became a member of a special committee that had to develop a new national approach. His opinion 
about what should be done had not fundamentally changed, since, in 1948, he declared that, based on the findings of his earlier study, he had the impression "that the problem [of woonwagenbewoners] has not been given other aspects" (van Doorn, quoted in van Ooijen 1993, p. 175), short for his idea that nothing had really changed and, thus, that his earlier proposal was still relevant. To promote his approach, he provided the committee members with copies of his 1940 series of articles entitled "The living wagons should disappear" (De woonwagens moeten verdwijnen).

In 1952, the committee presented a report about the situation of woonwagenbewoners and how it and their housing and education should be reorganized. The committee included a proposal for a new law dedicated to the materialization of its policy proposal. Two of the main measures the committee recommended were a ban on the moving of wagons and the reorganization and larger concentration of their sites in so-called 'regional camps', organized in each of the Dutch counties. The prohibition of free movement of wagons was considered to be the most effective way to reduce the 'nuisance' woonwagenbewoners would cause. The reasons for the larger, provincial concentration of caravan sites were, according to the committee, the installation of "sufficient surveillance", not the least regarding the education of the children of woonwagenbewoners, and the delivery of "decent facilities", even though preferably organized in a "sober" but "socially responsible way" in regions that offered "sufficient employment" (quoted in van Ooijen 1993, p. 176).

Of the two key measures proposed by the committee - formally similar to the two first measures the Nazis had imposed on woonwagenbewoners during the occupation -, the first would not, or at least not explicitly, make it into what would become the second Caravan Act of 1968 (van Ooijen 1993; Cottaar 1996, 1998). In order to achieve that travelling among woonwagenbewoners would be discouraged, the 1968 Act, like its 1918 predecessor, relied strongly on via-political interventions. Furthermore, van Doorn's proposal of the early 1940s to implement measures towards the 'moral upbringing' of woonwagenbewoners became one of the 1968 Act's key aims. These two components - the one more via-political, the other more biopolitical - would be merged with what could be considered the racializing condition of the new Act, as I will argue below. 


\section{The Production of Racial Difference Through Combined Biopolitics and Viapolitics}

In the 1968 Act, the living wagon is redefined as "a wagon that is used constantly or almost constantly as a home or intended for that purpose". Remarkable is the addition that a wagon does not stop to be one "due to the fact that the wheels are removed from underneath or the living or sleeping area is expanded by means of an earth-stable extension (aardvast aanbouwsel)" (quoted in van Ooijen 1993, p. 199, emphasis added). Similarly awkward requirements as in the 1918 Act were included in the 1968 one, such as the regulation that "a wagon may not be inhabited by a greater number of people than the number of square meters of floor space of the wagon divided by $21 / 2$ " (ibid.); a measure that strictly limited the maximum number of inhabitants of a wagon through its definition and size and, thus, tried to limit them through using viapolitics.

Before reflecting on the specificity of the via-political technologies implicated in the 1968 Act, I want to underline its intersecting moralizing and racializing dimensions. In particular after 1945, the emphasis on the importance of social care, 'moral upbringing' and the education of children of woonwagenbewoners had become increasingly dominant. While, before the war, this domain had been mostly the terrain of church organizations, afterwards a newly established faith-based organization - the R.K. Vereniging van Woonwagen Liefdewerken (Roman Catholic Society of Caravan Charities) - offered its charity services to the government in exchange for subsidies (Cottaar 1998, pp. 125-26). The post-war reformulation of the policy towards woonwagenbewoners in terms of social welfare, rather than primarily public order - as in the 1918 Act - was also articulated through the 1957 shift of governmental responsibility for this policy from the Ministry of Justice to that of Social Welfare (Cottaar 1998, p. 126, see also van Beugen et al. 1976). The philosophy behind the shift from various small municipal camps to a limited number of large regional ones also related to this emphasis on 're-educating' woonwagenbewoners. The Act required the establishment of 50 regional camps, each with halting sites for 50 to 80 wagons and all equipped with their own schools - 'special' ones - general practitioners, social workers, and other facilities, such as connection to the sewage system, electricity, and toilets for each wagon, and fire protection, central lighting, and access to main infrastructure in and for each camp - which was now no longer called a 'camp', but a 'center' to avoid direct connotations with the camps installed by the Nazis. 


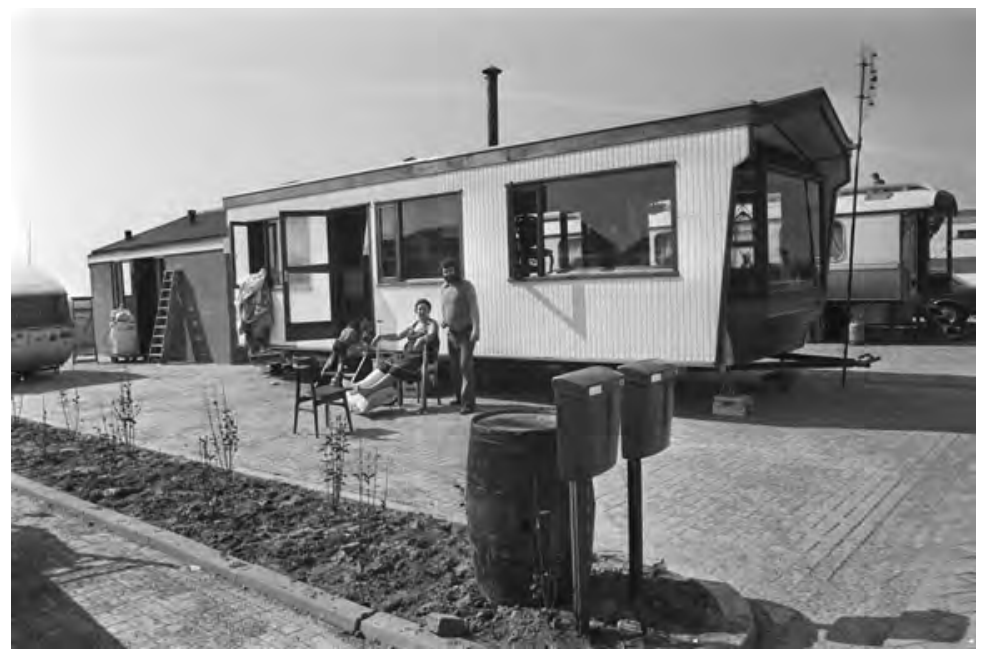

Fig. 5: Modern 'mobile home' (stacaravan) with an 'earth-stable extension' (aardvast aanbouwsel) at the Kloosterdijk, Monnickendam, 15 April 1980 (Nationaal Archief CCO; Photo: Fernando Pereira)

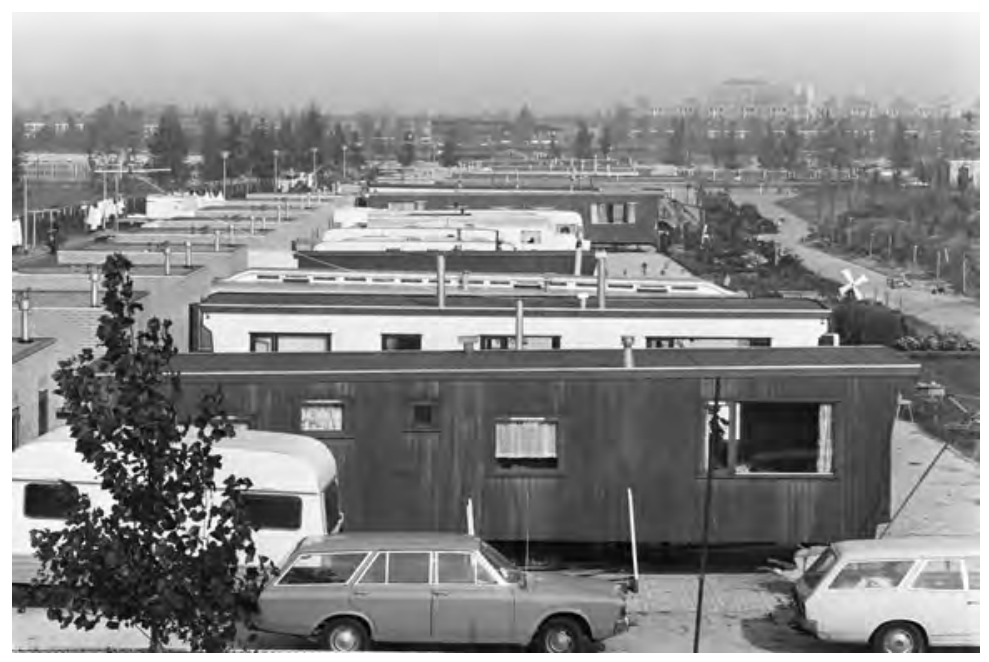

Fig. 6: Center for living wagons (woonwagencentrum) with 'earth-stable extensions' at the Noord Akerweg, Amsterdam Osdorp, 17 October 1975 (Nationaal Archief CCO; Photo: Rob Croes) 
Through this 'civilizing offensive', camp inhabitants had to 'teach themselves' the benefits of living sedentarily and, ultimately, refrain from continuing living in a wagon. The description of one of the aims of one of the first regional camps is exemplary in this respect:

"By means of a clean halting site, an own shed with heating facilities ..., a private toilet and garbage bin (bygiene promotion within one's own reach) [and] a private electricity meter ... needs are learned (aangekweekt) unnoticed, making travelling increasingly difficult for psychological and material reasons. The management of the regional camp ... expects to achieve in such a way that the woonwagenbewoner, in complete freedom, comes to the realization that not only travelling has lost its attractiveness, but also living in a wagon.” (Janssen 1962, quoted in van Ooijen 1993, p. 227, emphasis added)

The most striking, but often neglected or denied aspect of the 1968 Act was the racial demarcation of the population group for whom the law was explicitly meant. ${ }^{6}$ Remarkably, the Act allows that a permit for living in a wagon is also granted when "the applicant can prove that he $[s i c] . .$. has previously lived in a woonwagen" (quoted in van Ooijen 1993, p. 199). Even more radical: a permit has also to be granted to persons who - even when they themselves never lived in a wagon - can prove that their parents have ever received a permit or when they have actually lived in a wagon. Thus, the decisive feature for the distinction between a 'living wagon' and a house in the sense of the Housing Law is not only the kind of wagon/ house, but also the kind of inhabitant. The Act determines that only when inhabitants belong to the group of 'traditional' woonwagenbewoners or can prove that their parents belonged to it, they are considered as people living in a living wagon, as defined by the Act (van Ooijen 1993, p. 199)! This decisive feature is all the more remarkable if we take into account that, in the 1968 Act, those who were living in a wagon and continued travelling for professional reasons - this category mainly included fairground operators,

6 While van Ooijen (1993, pp. 199-200) straightforwardly denies that the reference to descent could be understood as a process of racialization, Cottaar (1998) does mention the relevance of this reliance on descent for the 'making of a minority', but fails to qualify it in terms of racialization, something that seems to be related to the reluctance of the 'Dutch School' of Wim Willems, Leo Lucassen and Annemarie Cottaar to formulate stigmatization in terms of intersecting racializing processes and minority self-articulation in those of ethnicity and ethnicization (for an extensive discussion of this debate, see van Baar 2011a, Ch. 3, 4). 
circus artists, and road builders - were not considered as the woonwagenbewoners for which the Act and the regional centers were meant. ${ }^{7}$

Thus, two categories of woonwagenbewoners were now carefully distinguished: those who were travelling for professional reasons, and those who belonged to the 'category of so-called travellers' (de categorie der zogenaamde reizigers), also called the 'original woonwagenbewoners' (woonwagenbewoners van origine), for whom the regional centers were strictly meant. The category of new woonwagenbewoners that already emerged before the war and that had its origin in the housing shortage was no longer taken into account. From the very beginning, these inhabitants of what could better be called 'mobile homes' were considered as citizens in its understanding of burghers (burgers) who were perceived having a solid 'sedentary' background. As Annemarie Cottaar (1998, p. 127) rightly observed, in the end "the controversial ban on travelling was smuggled into the law in disguised form." Whereas the purported "traditional" or "original" woonwagenbewoners "kept their right to move about, ... they were no longer allowed to station their homes anywhere outside a regional camp [and] ... official permission was [now] required to change camps" (ibid., emphasis added).

In this way, the Act introduced a series of regulations that turned the regional centers into sites of a civilizing offensive, which defined their inhabitants on the racializing basis of descent, which limited their mobility according to an implicitly formulated travel ban (contained mobility) and which legitimated the establishment of substandard public services, including, most notably, education in 'special' schools, in the regional centers. The lawyer Lau Mazirel (1968/1987) was among the first who pointed to the racism - she called it the reliance on descent (afstammingsbeginsel) - implicated in the 1968 Act and the troublesome, and in fact fully indecisive and therefore entirely arbitrary way in which the different categories of woonwagenbewoners were distinguished. What Cottaar (1998) has called the "making of a minority" - referring to the case of the Dutch ('traditional') woonwagenbewoners - occurred to a significant extent through racialization, and led to systematically subordinating the minority members, including those with Sinti or Roma backgrounds.

The Act's racializing condition also prevented that the new definition of the woonwagen - with or without wheels and with or without further

7 Importantly, this category of people was not considered 'problematic', because municipalities usually found ways to grant them temporary permission to stay on a site related to their professions. 
extensions - would seriously affect 'burghers' living in a mobile home. The 'moral upbringing' and discouraging of travelling took place not only through the biopolitical treatment of the involved woonwagenbewoners, but also and considerably through the via-political treatment of the woonwagen. Indeed, it was the wagon that had to be rooted, if not directly through legally requiring its connection with sewage, water, gas or electricity systems, then indirectly through what the 1968 Act called "earth-stable extensions". What if we simply turn the 'living wagon' into a 'mobile home' (stacaravan) that is (almost) impossible to move? This effort perfectly characterizes the final episode of the Dutch policy that I want to discuss.

In the 1970s, the supply of wagons was increasingly transferred to the government. The stricter regulations regarding the ways in which the wagons had to be equipped led to a situation in which the government itself was going to fabricate wagons that were, from then on, subsidized ones; a form of financial support for woonwagenbewoners that was going to be organized in a new law, initiated in 1981. This law introduced yet another definition of the woonwagen: now it must be at least $9.2 \times 3.5 \times 3$ meters in size to qualify for a financial contribution from the Ministry of VROM (Public Housing, Spatial Planning, and the Environment). As van Ooijen remarks, transporting such a huge wagon behind a car was not in accordance with the official road traffic regulations and, thus, illegal(ized). He adds: "not only misses a wagon [of such a size] its wheels, but its construction also does not allow having wheels fitted underneath" (van Ooijen 1993, p. 288, emphasis added).

With the implementation of the 1981 Act on financial support for woonwagens, so-called 'VROM wagons' were introduced, called after the Ministry of Public Housing, Spatial Planning, and the Environment. These were mobile homes, owned by the municipalities, mostly rented by woonwagenbewoners, written off in 15 years, and with a lifespan of approximately 25 years. In the 1980s, most of the older 'living wagons' were systematically replaced by VROM wagons, which fulfilled all official requirements, simply because the Dutch state produced them. The 1981 Act still offered some space for the former 'living wagon': it showed up with an 'entirely' new definition of what the Act now calls a 'travelling wagon' (trekkerswagen). This was a wagon meant to be moved on by a car, in full accordance with road traffic regulations. Yet, this 'travelling wagon' could not count on financial support from the government. After the neoliberalization of social policies and the 1999 abolition of the 1968 Act, the delivery of mobile homes for woonwagenbewoners was privatized and, increasingly, they could also buy their mobile homes. 


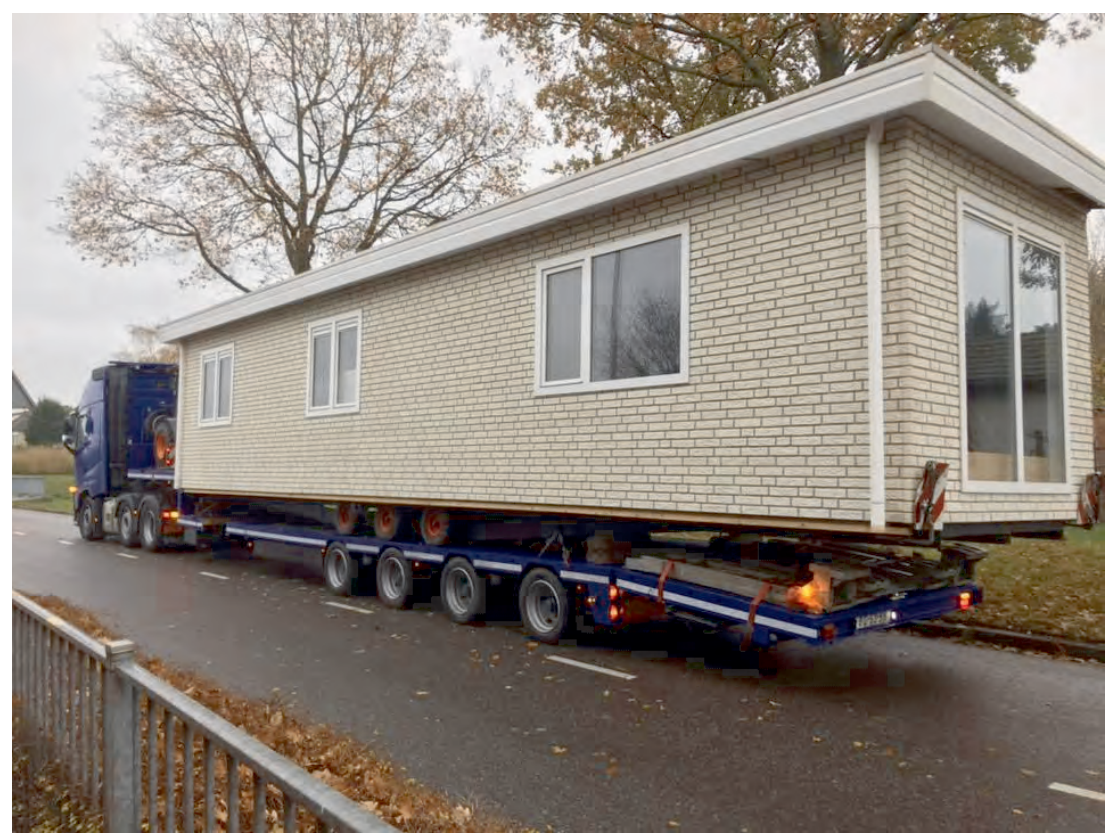

Fig. 7: Trailer transportation of a modern 'mobile home' (stacaravan) by the private company Handelsonderneming Bram Bakker (Photo: Bram Bakker)

In summary, we could say that the living wagon has been substantially if not entirely 'governmentalized', that is, made amenable to political technologies of government. I will do harm to this history if I suggest that this via-political trajectory did not include resistant moments of counterconduct as well, ${ }^{8}$ even though these have impacted only marginally to the

8 Such a moment occurred in the 1970s, when Koko Petalo (1942-96), an influential and controversial leader of Roma in the Netherlands, decided to occupy public spaces with caravans and cars to claim amnesty for Yugoslav Roma who had arrived in the Netherlands. In the course of the 1970s, he occupied, among other sites, a space next to the Royal Palace in Soestdijk, the front court of the Dutch Parliament in The Hague, and the central Dam Square in Amsterdam to create public attention for and indignation about how the Yugoslav Roma were repeatedly forced to leave the country until, finally, in 1977-78, the Dutch government would grant amnesty and Dutch citizenship to a significant part of these Roma (see also Willems/Lucassen 1990; Rijken 2012). 
current state of affairs in which municipalities still refer - officially and unofficially - to (the desirability of) extinction policy.?

\section{Concluding Remarks}

In this chapter, by examining the case of Roma, I have tried to answer the question of how we could shed better light on the complexity and multiplicity of governmentalities and counter-governmentalities that have been practiced regarding 'mobile' and allegedly 'unruly' groups. Through considering nomadization and viapolitics as key dimensions of governing dispersed populations that intersect with the biopolitical dimensions that have been extensively discussed in the literature, we can diversify these governing technologies and rationalities and make them more susceptible to mobile governmentalities and strategies of governing not only of, but also through mobility (van Baar 2011b, 2015, 2018, 2019; Tazzioli 2020). This insight implies that we have to understand not only various kinds of 'camps' (refugee, migrant, 'Gypsy') as technologies of governing, but also mobility itself, as well as the 'via's' that channel and challenge the movement of 'disorderly' people, and of irregularized migrants and racialized minorities in particular. Thus, while the biopolitical dimensions related to 'camps' as political technologies still tend to privilege the relatively fixed structures of containment, an examination of nomadization and viapolitics can undo this fix through underlining the importance of mobility and its infrastructures in the governing of 'unruly' mobilities.

If we understand 'race' as a technology of the management of human difference that aims at the production, maintenance or even reinforcement of power relations that articulate such human difference hierarchically (Hall 2017; Lentin 2020), we can consider viapolitics, just as biopolitics, as a specific governmental technology that can significantly contribute to enacting racial and social difference. Therefore, in line with those who have underlined the importance of viapolitics as a prominent governing technology at the nexus of security and mobility (Tazzioli 2020; Walters 2015a, 2015b; Walters et al. 2022), my examination contributes to the debate

9 In 2017, and due to continuous protests of the Dutch Association for Woonwagenbewoners, Sinti and Roma, a court case against Dutch municipalities that still practiced extinction policy was won in favor of the involved Roma groups. 
about how we could or should understand mobile governmentalities in historical and contemporary practices of racialization and securitization. ${ }^{10}$

\section{Works Cited}

Cottaar, Annemarie (1996): Kooplui, kermisklanten en andere woonwagenbewoners: Groepsvorming en beleid 1870-1945. Amsterdam: Het Spinhuis.

Cottaar, Annemarie (1998): The Making of a Minority: The Case of Dutch Travellers. In: Lucassen, Leo/Willems, Wim/Cottaar, Annemarie (eds): Gypsies and other Itinerant Groups. London: Macmillan Press, pp. 114-132.

Council of Europe (1969): Situation of Gypsies and other travellers in Europe. Recommendation 563 (1969). Strasbourg.

Council of Europe (1975): Social Situation of Nomads in Europe. Resolution (75) 13. Strasbourg.

Danbakli, Marielle (ed.) (2001): Roma, Gypsies: Text issued by International Institutions. Hatfield: University of Hertfordshire Press.

Foucault, Michel (1975/1995): Discipline and Punish. New York: Vintage.

Foucault, Michel (2007): Security, Territory, Population: Lectures at the Collège de France 1977-1978. New York: Palgrave Macmillan.

Hall, Stuart (2017): The Fateful Triangle: Race, Ethnicity, Nation. Cambridge, MA: Harvard University Press.

Janssen, P. (1962): Woonwagenbewoners. A series of articles in the journal Sociale Zorg 24(5-6, 9-11).

Le Bas, Damian (2018): The Stopping Places: A Journey Through Gypsy Britain. London: Vintage.

Legros, Olivier/Lièvre, Marion (2019): Domestic versus State Reason? How Roma Migrants in France deal with their Securitization. In: van Baar, Huub/Ivasiuc, Ana/Kreide, Regina (eds): The Securitization of the Roma in Europe. New York: Palgrave Macmillan, pp. 67-87.

Lentin, Alana (2020): Why Race Still Matters. Cambridge: Polity.

10 The ways in which I have investigated dimensions of viapolitics primarily relate to how authorities have tried to govern Roma mobilities, and less to how Roma themselves have been involved in their own government and, thus, have also developed counter-governmentalities. Historically, the former type of viapolitics has always coincided with manifestations of counter-conducts in which Roma have demonstrated that they do not want to be governed 'this way'. Throughout history and up till now, Roma have frequently routed and rerouted their trajectories and journeys to circumvent or challenge particularly harsh governmental interventions in order to create new opportunities for the ways they want to live their lives and, without romanticizing them, they have also done so more or less successfully in many cases (see, e.g., Le Bas 2018; Legros/Lièvre 2019). 
Mazirel, Lau (1968/1987): "Nieuwe regelen ter bevordering van het maatschappelijk welzijn van de woonwagenbevolking” (Woonwagenwet). In: Mazirel, Lau: Woonwagenvolk. Amsterdam: Van Gennep, pp. 25-40.

Nyers, Peter (2019): Irregular Citizenship, Immigration and Deportation. London: Routledge.

Picker, Giovanni (2017): Racial Cities. London: Routledge.

Picker, Giovanni/Greenfields, Margaret/Smith, David (2015): Colonial Refractions: The 'Gypsy Camp' as a Spatio-Racial Political Technology. In: City 19:5, pp. 741-752.

Rijken, Kemal (2012): Roma. Amsterdam: Bertram + de Leeuw Uitgevers.

Tazzioli, Martina (2020): Governing Migrant Mobility through Mobility: Containment and Dispersal at the Internal Frontiers of Europe. In: Environment and Planning C: Politics and Space 38:1, pp. 3-19.

van Baar, Huub (2011a): The European Roma: Minority Representation, Memory and the Limits of Transnational Governmentality. Amsterdam: F\&N.

van Baar, Huub (2011b): Europe's Romaphobia: Problematization, Securitization, Nomadization. In: Environment and Planning D: Society and Space 29:2, pp. 203-212.

van Baar, Huub (2015): The Perpetual Mobile Machine of Forced Mobility: Europe's Roma and the Institutionalization of Rootlessness. In Jansen, Yolande/ Celikates, Robin/de Bloois, Joost (eds): The Irregularization of Migration in Contemporary Europe: Detention, Deportation, Drowning. Lanham, MD: Rowman and Littlefield, pp. 71-86.

van Baar, Huub (2017): Evictability and the Biopolitical Bordering of Europe. In: Antipode 49:1, pp. 212-230.

van Baar, Huub (2018): Contained Mobility and the Racialization of Poverty in Europe: The Roma at the Development-Security Nexus. In: Social Identities 24:4, pp. 442-458.

van Baar, Huub (2019): From 'Lagging Behind' to 'Being Beneath'? The De-developmentalization of Time and Social Order in Contemporary Europe. In: van Baar, Huub/Ivasiuc, Ana/Kreide, Regina (eds): The Securitization of the Roma in Europe. New York: Palgrave Macmillan, pp. 159-182.

van Baar, Huub (2021): The Production of Irregular Citizenship Through Mobile Governmentalities: Racism Against Roma at the Security-Mobility Nexus. In: Mobilities 16:5, pp. 809-823.

van Beugen, Marinus/Burgmans, A./van Schaijk, H. (1976): Wonen op wielen: Woonwagenbeleid als toetssteen van welzijnsbeleid. Nijmegen: Nijmeegs Universitair Instituut voor Sociale Pedagogiek en Andragogiek.

van Doorn, L.A. (1940): De woonwagens moeten verdwijnen. In: Sociale Zaken 2: pp. 453-456, 469-472, 485-488, 501-504.

van Ooijen, David (1993): 'Je moet weg, hier komen mensen wonen': Woonwagenbeleid in Nederland 1890-1990. The Hague: Sdu Uitgeverij Koninginnegracht.

Walters, William (2015a): Migration, Vehicles and Politics: Three Theses on Viapolitics. In: European Journal of Social Theory 18:4, pp. 469-488. 
Walters, William (2015b): On the Road with Michel Foucault: Migration, Deportation and Viapolitics. In: Fuggle, Sophie/Lanci, Yari/Tazzioli, Martina (eds): Foucault and the History of our Present. New York: Palgrave Macmillan, pp. 94-110.

Walters, William/Heller, Charles/Pezzani, Lorenzo (eds.) (2022): Viapolitics: Borders, Migration, and the Power of Locomotion. Durham, NC: Duke University Press.

Willems, Wim/Lucassen, Leo (1990): Ongewenste vreemdelingen: Buitenlandse zigeuners en de Nederlandse overheid. The Hague: Sdu. 